Krzysztof T. Wieczorek*

ORCID: 0000-0002-7987-168X

Katowice

\title{
Przestrzenie wolności: między heroizmem a konformizmem
}

Józefa Tischnera najczęściej określa się mianem filozofa ludzkiej nadziei. Mówi się o nim także jako o twórcy filozofii dramatu i wybitnym przedstawicielu myśli dialogicznej. Stosunkowo rzadko zwraca się uwagę na inny wątek, który w twórczości myśliciela z Łopusznej zajmuje nie mniej poczesne miejsce niż wymienione wcześniej: chodzi o problem wolności. Zagadnieniem tym zajmował się Tischner niemal od samego początku swej filozoficznej i teologicznej refleksji. W jego pierwszej publikacji książkowej - wydanym w 1975 roku zbiorze wcześniej publikowanych artykułów, zatytułowanym Świat ludzkiej nadziei - zostały zamieszczone dwa teksty poświęcone wolności: „W poszukiwaniu istoty wolności” (pierwodruk w miesięczniku Znak 7-8 (1970): 821-838) oraz „Etos wolności” (Znak 2 (1975): 185-194). Coraz bardziej pogłębione zainteresowanie tym problemem towarzyszyło jego drodze myślowej do samego końca.

W marcu 2001 roku ukazał się specjalny numer miesięcznika Znak, który - jak wyjaśniają redaktorzy we wstępie - „miał być dla Tischnera urodzinowym prezentem" ". Zrządzeniem Opatrzności Jubilat nie doczekał wręczenia tego prezentu (zmarł 28 czerwca 2000 roku). Nie zmieniło to jednak

* Prof. dr hab. Krzysztof T. Wieczorek, kierownik Zakładu Logiki i Metodologii w Instytucie Filozofii Uniwersytetu Śląskiego w Katowicach. Adres: Instytut Filozofii Uniwersytetu Śląskiego, ul. Bankowa 11, 40-007 Katowice; e-mail: krzysztof.t.wieczorek@us.edu.pl.

1 „Od redakcji”, Znak 550 (2001): 3. 
faktu, że zeszyt monograficzny, zatytułowany „Tischner. Religia i wolność”, został niemal w całości poświęcony zaprezentowaniu sylwetki duchowej i intelektualnej oraz dorobku człowieka, który „wywarł ogromny wpływ na Polskę i na Kościół, na nasze myślenie i naszą religijność"2, a najwyraźniej zaakcentowanym przez autorów i redaktorów marcowego numeru czasopisma motywem jego twórczości stała się wolność.

Szczególnie utkwiły nam w pamięci jego słowa z Nieszczęsnego daru wolności: „Bóg jest Tym, który wyzwala. [...] Wolność jest jakby bramą, przez którą wchodzi się do wnętrza chrześcijańskiego domostwa. Człowiek, który otrzymuje łaskę wiary, odkrywa, że teraz dopiero jest naprawdę wolny". Ksiądz Józef Tischner był człowiekiem wolnym ${ }^{3}$

- czytamy w słowie „Od redakcji”. Należy dodać: nie tylko sam był człowiekiem wolnym, i to niezależnie od okoliczności politycznych, historycznych czy biograficznych, ale równocześnie był niestrudzonym głosicielem i wnikliwym badaczem idei wolności oraz jej oddziaływań na konkretne losy ludzi, społeczeństw i narodów.

Poniższy tekst stanowi próbę rekonstrukcji Tischnerowskich przemyśleń nad najnowszymi dziejami polskiego społeczeństwa doby schyłkowego socjalizmu oraz okresu transformacji ustrojowej pod kątem stosunku do problemu wolności. Krakowski filozof w swych analizach daleki był od łatwego optymizmu; nie starał się przypisywać Polakom niezasłużonych zalet, lecz $\mathrm{z}$ bezstronną dociekliwością rzetelnego badacza obserwował polski etos narodowy i jego kolejne przemiany, próbując dociec przyczyn rosnącej w miarę postępu dziejów rozbieżności między nadzieją i oczekiwaniem na coraz doskonalszą realizację ideału wolności w realiach polityki nowego kształtu państwa, które zrzuciło jarzmo komunizmu, a rzeczywistością budzącą pod niejednym względem bolesne rozczarowanie.

Te procesy społeczne i moralne, które obserwował i analizował Tischner do samego końca swej filozoficznej aktywności, nie skończyły się wraz z jego odejściem; trwają dalej i w niektórych aspektach - również tych, które najbardziej niepokoiły myśliciela - jeszcze się pogłębiają. Dlatego warto w dalszym ciągu pytać, obserwować i prowadzić refleksję w sposób wytyczony przez oryginalne rozważania księdza Tischnera nad dzisiejszym kształtem przestrzeni wolności wśród Polaków, ze szczególnym uwzględ-

\footnotetext{
2 Tamże.

3 Tamże.
} 
nieniem namysłu nad zmiennym dynamizmem ludzkiego balansowania między heroizmem a konformizmem. Taki jest zamysł niniejszego artykułu.

\section{Rodzaje źródłowych doświadczeń wolności według Tischnera}

„Wolność jest jedna, ale objawia się ona rozmaicie, zależnie od okoliczności. Toteż wszystkim filozofom, którzy mianują się jej obrońcami, należałoby postawić jedno pytanie wstępne: w związku z jaką szczególną sytuacją doświadczaliście waszej wolności?" - pisał Jean-Paul Sartre w eseju „Wolność Kartezjańska”4. Zastanówmy się pokrótce, jak na zadane przez Sartre'a pytanie odpowiedziałby Józef Tischner. Myślę, że na podstawie analizy jego tekstów można by wskazać trzy rodzaje źródłowych doświadczeń wolności: pierwsze - spotkanie z drugim człowiekiem, którego postrzegamy jako osobę cieszącą się wolnością; drugie - cierpienie spowodowane świadomością zniewolenia, które rodzi tęsknotę za wolnością; trzecie - żywe doświadczenie stopniowego wyzwolenia. Przyjrzyjmy się kolejno tym trzem obszarom.

W książce Nieszczęsny dar wolności autor zauważa: „Człowiek, który przychodzi na świat, nie wie, co to jest wolność. Ale może się dowiedzieć,

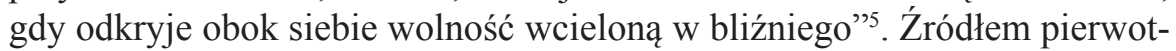
nego doświadczenia wolności może więc być wzór osobowy, obecny w otoczeniu człowieka. Obcowanie z wolną osobą jest potencjalnym źródłem wiary, że ja też mogę być wolny.

Jednak nie każde spotkanie otwiera nas na doświadczenie wolności, promieniującej od strony spotkanego człowieka. Bywają - twierdzi Tischner - również innego rodzaju spotkania. Takie, których treścią jest groźba i wywołany przez nią lęk, a możliwym rezultatem - zniewolenie. Ten typ spotkań krakowski filozof analizuje w dziele Filozofia dramatu, opisując je następująco:

czym grozi mi inny człowiek, czym może mi on w ogóle zagrozić? [...] może mnie zabić - to pierwsza możliwość; [...] może mi zadać dłużej lub krócej trwające cierpienie - to możliwość druga. I wreszcie może mnie zniszczyć mo-

${ }^{4}$ Jean-Paul Sartre, „Wolność Kartezjańska”, w: Filozofia i socjologia XX wieku, t. II, red. Bronisław Baczko (Warszawa: Wiedza Powszechna, 1965), 309.

5 Józef Tischner, Nieszczęsny dar wolności (Kraków: Znak, 1993), 11. 
ralnie, może mnie potępić, pozbawić poczucia godności i wszelkiego szacunku, jakim się cieszę u ludzi. [...] Cóż jest celem groźby? Jest nim jakieś mniej lub bardziej trwałe, mniej lub bardziej głębokie zniewolenie człowieka. [...] Groźba pozostaje w ścisłym stosunku do zniewolenia, a stawianie oporu groźbie jest formą walki o wyzwolenie 6 .

Doświadczenie wyzwolenia jako sposób obcowania z problemem wolności opisuje ksiądz Tischner na przykładzie chrześcijańskiego stosunku do grzechu jako stanu wewnętrznej niewoli: „wolność chrześcijańska jest żywym konkretem [...]. Żywe doświadczenie wolności obecne w duszach ludzi, którzy są niewolnikami grzechu, nie jest doświadczeniem wolności czystej lub wolności absolutnej, lecz doświadczeniem stopniowego wyzwolenia"7 - w odróżnieniu od „wolności oświeceniowej”", o której Sartre pisał następująco: „Richelieu, Wincenty a Paulo, Corneille [...] uchwycili jedną jej stronę, w chwili gdy objawiała się ona jako zdarzenie absolutne"."

Warto dodać, że (ściśle konfesyjne) doświadczenie wewnętrznego wyzwolenia z niewoli grzechu nie jest u Tischnera jedyną egzemplifikacją tego rodzaju doświadczenia. Niemało uwagi poświęcił bowiem krakowski filozof również sytuacjom, gdy przedmiotem doświadczenia jest stopniowe wyzwalanie się z dotkliwych ograniczeń, narzucanych przez opresyjną władzę ${ }^{10}$.

Wszystkie te doświadczenia rodzą tęsknotę za wolnością jako rysującą się przed nami możliwością i zachęcają do konstruowania projektów bycia wolnym (choć stoją za nimi różne modele wolności, generujące różnego rodzaju nadzieje i oczekiwania). Równocześnie konfrontują nas ze świadomością ceny, jaką nieuchronnie trzeba zapłacić za wyzwolenie. Wolność bowiem - zwłaszcza ta prezentująca się przez kontrast z doświadczeniem

6 Józef Tischner, Filozofia dramatu (Kraków: Znak, 1998), 194.

7 Tischner, Nieszczęsny, 11-12.

8 Tamże, 12.

9 Sartre, „Wolność”, 309.

10 Zob. np. artykuł: Józef Tischner, „Człowiek zniewolony i sprawa wolności”, Znak 319-320 (1981): 123-142. Por. Józef Tischner, Polski ksztatt dialogu (Paris: Editions Spotkania, 1981), gdzie w refleksjach na zakończenie autor pisze, że ,jednym z doniosłych efektów dialogu [między władzą a społeczeństwem - K. T. W.] jest istniejąca w naszym kraju przestrzeń wolności. Wiemy, że jest ona większa niż w innych podobnych do naszego krajach. Nikt nie ma złudzeń co do tego, że osiągnięcie takiej przestrzeni wolności jest zasługą chrześcijańskiego ducha oporu, pracy duszpasterskiej Kościoła, a także posoborowej teologii [...]. Wizyta Jana Pawła II przestrzeń tę poszerzyła i umocniła, a także dodała ducha tym, którzy nad jej poszerzeniem pracują" [190-191]. 
zniewolenia - jawi się jako wartość, o którą trzeba walczyć i za którą trzeba coś ważnego poświęcić. Dlatego podjęcie decyzji, by wejść na drogę prowadzącą ku wolności, wymaga niemałej odwagi, a niekiedy nawet heroizmu.

\section{Wolność jako trudne do uniesienia brzemię}

Wbrew ugruntowanym $\mathrm{w}$ naszej kulturze przeświadczeniom, że wolność jest naturalnym celem ludzkich dążeń, że - jak to wyraził Sartre - „wolność jest podstawą bytu, jego utajonym wymiarem"11, Tischner dopuszcza inną możliwość: podążając za myślą Ericha Fromma, rozważa hipotezę, że być może „człowiek wcale nie dąży do wolności, wolność jest dla niego ciężarem nie do uniesienia, dąży raczej do pozbycia się wolności, do zrzucenia ciężaru odpowiedzialności”" ${ }^{2}$. W książce Nieszczęsny dar wolności rozpoczyna swą refleksję nad kondycją duchową polskiego społeczeństwa lat dziewięćdziesiątych XX wieku od niepokojącego, dalekiego od optymizmu pytania:

Czy nie stajemy się dziś ofiarami nowego, nieznanego nam dotąd lęku - lęku przed wolnością? Jeszcze nie tak dawno potwierdzaliśmy dzielnie naszą tożsamość w oporze przeciw gwałtowi, a dziś - odnoszę wrażenie - nie potrafimy spojrzeć w głąb odzyskanej wolności. [...] Może się mylę, ale często - bardzo często - widzę, jak nasz lęk przed wolnością staje się większy niż lęk przed przemocą ${ }^{13}$.

Te pytania i obawy księdza Tischnera - trudne, kontrowersyjne, bolesne - skłaniają do zastanowienia się nad duchową kondycją polskiej wspólnoty narodowej w momencie rozpoczęcia procesu transformacji ustrojowej. Czy byliśmy wówczas spragnieni wolności i gotowi na jej przyjęcie, czy - po upływie ponad 40 lat funkcjonowania w ustroju, zwanym socjalistycznym tak głęboko przesiąknięci skłonnością do biernego oportunizmu, zapewniającego skromne, lecz w miarę wygodne warunki codziennej egzystencji, że perspektywa radykalnej zmiany budziła w dużej części społeczności raczej przerażenie, a co najmniej niepokój niż entuzjazm i satysfakcję?

\footnotetext{
11 Sartre, „Wolność”, 329.

12 Tischner, „Człowiek”, 131.

13 Tischner, Nieszczęsny, 7.
} 
W odniesieniu do niełatwych początków naszej najnowszej drogi do wolności zaskakująco aktualnie brzmią ważkie słowa Jana Jakuba Rousseau, pisane w czasach odległych (w 1754 roku), lecz widocznie pod pewnym względem podobnych:

$\mathrm{Na}$ temat umiłowania wolności popełniają nasi politycy sofizmaty takie same, jakie nasi filozofowie na temat stanu natury; z tego, co widzą, wnioskują o rzeczach, których nie widzieli, bardzo odmiennych; i tak przypisują ludziom wrodzoną skłonność do poddaństwa z tej racji, że ci, których mają przed oczyma, znoszą swe poddaństwo cierpliwie; ani im na myśl nie przyjdzie, że z wolnością ma się rzecz nie inaczej niż z niewinnością i cnotą, których wartość ten tylko czuje, kto się cieszy ich posiadaniem, i do których upodobanie traci człowiek wraz z nimi samymi. [...] Toteż nie z upodlenia ludów niewolnych sądźmy o tym, czy człowiek z natury czuje skłonność do poddaństwa, czy niechęć, ale z tych niepojętych wprost cudów, jakich wszystkie ludy wolne dokonywały, by uchronić się przed uciskiem [...] kiedy widzę, jak te ostatnie poświęcają przyjemności, spokój, bogactwo, potęgę i życie samo, by zachować to dobro jedyne, tak przez tych, którzy je stracili, wzgardzone [...], czuję, że nie niewolników jest rzeczą wydawać sąd o wolności ${ }^{14}$.

Kim więc jesteśmy - my, świadkowie i uczestnicy trudnego historycznego procesu wychodzenia $\mathrm{z}$ utartych torów życia ukształtowanego przez warunki i okoliczności realnego socjalizmu: niewolnikami usiłującymi wydawać sądy o wolności czy potomkami i pełnoprawnymi spadkobiercami wolnego ludu, poświęcającego przez pokolenia przyjemności, spokój, bogactwo, potęgę i życie samo, by wybić się na niepodległość?

\section{Homo sovieticus i jego roszczenia a sprawa wolności}

W książce Homo sovieticus Józef Tischner pisał:

Żyć w komunizmie znaczyło stać w thumie przed komunistycznym straganem, na którym sprzedawano nieco towarów i wiele obietnic, takich jak powszechna równość i sprawiedliwość, powszechny dobrobyt, nieograniczony żadnymi

14 Jean-Jacques Rousseau, „Rozprawa o pochodzeniu i podstawach nierówności między ludźmi”, w: Jean-Jacques Rousseau, Trzy rozprawy z filozofii społecznej (Warszawa: PWN, 1956), 211-212. 
przeszkodami postęp pracy, wolność od ucisku klasowego, narodowego, rasowego, pokój i w ogóle szczęście ludzkości. Klęska komunizmu oznacza, że stragan... zawalił się. [...] Czy jednak fakt zawalenia się straganu oznacza, że zmienili się klienci przed straganem ${ }^{15}$

W dopisanym po kilku latach (w 1996 roku) autokomentarzu dodał:

Wciąż jeszcze żyje kilka pokoleń, które nie są w stanie określić siebie inaczej niż poprzez odniesienie do komunizmu. Niezależnie od tego, czy ludzie ci byli „za”, czy „przeciw”, są tym, czym są - poprzez komunistów. Mówi się, że po klęsce komunizmu pozostało społeczeństwo roszczeniowe. O jakie roszczenia chodzi? ${ }^{16}$

Z pewnością nie o roszczenia do wolności, gdyż takich, rzecz jasna, ,komunistyczny stragan" nie oferował. W świetle niektórych wypowiedzi przedstawicieli polskich elit intelektualnych może się ukształtować wrażenie, że najważniejszym celem stojącym przed narodem po upadku opresyjnego systemu było odzyskanie ludzkiej godności osobowej, przez lata deptanej i deprecjonowanej w imię sztucznych, abstrakcyjnych i nieprzekonujących ideałów komunistycznego kolektywizmu. Czy jednak rzeczywiście taki cel przyświecał wówczas nam wszystkim?

Innego zdania jest na przykład Richard Barbrook ${ }^{17}$, który jeszcze w ostatnich latach rządów partii komunistycznej w PRL, a także już po oddaniu przez nią władzy, dostrzegł postępujący zanik wiary we wzniosłe ideały i abstrakcyjne wartości na rzecz trzeźwego, pragmatycznego realizmu. W „Przedmowie do wydania polskiego” swej książki Przyszłości wyobrażone. Od myślacej maszyny do globalnej wioski pisał on o roku 1989: „Nastał heglowski «koniec historii», czas, gdy utopijne sny przekształcane są w pragmatyczne rozwiązania" ${ }^{18}$. W odniesieniu zaś do schyłkowego okre-

15 Józef Tischner, Etyka solidarności. Homo sovieticus (Kraków: Znak, 2005), 199.

16 Józef Tischner, „Etyka solidarności po latach”, w: Józef Tischner, Etyka solidarności, 252.

${ }^{17}$ Richard Barbrook, ur. 1956 - brytyjski politolog i medioznawca, wykładowca Faculty of Social Sciences and Humanities na University of Westminster, laureat nagrody McLuhana w 2008 roku za książkę Imaginary Futures: from Thinking Machines to the Global Village; badacz ideologii i ich wpływu na życie społeczne.

${ }^{18}$ Richard Barbrook, Przyszłości wyobrażone. Od myślacej maszyny do globalnej wioski (Warszawa: Muza S.A., 2009), 12. 
su rządów PZPR przytacza w tym samym tekście usłyszaną w 1984 roku, charakterystyczną - jego zdaniem - dla tamtego czasu wypowiedź znajomej, polskiej lewicowej działaczki opozycyjnej, przebywającej na emigracji w Wielkiej Brytanii: „No wiesz, to już w zasadzie koniec. Nikt nie wierzy w system. Ani robotnicy, ani chłopi, ani nawet biurokraci"19.

Czy to jednak oznacza, że stara (mniej lub bardziej szczera, bo dla jednych stanowiąca autentyczną treść życia, a dla innych cynicznie pozorowana dla osiągnięcia kariery i awansu społecznego) wiara w „system”, który coraz wyraźniej ulegał rozpadowi, ustąpiła miejsca nowej wierze, ufundowanej na nadziei zbudowania własnego, samodzielnego modelu rozwoju społecznego na miarę ambicji tej części świata, którą geopolityczne uwarunkowania usytuowały tak nieszczęśliwie „na wschód od Zachodu i na zachód od Wschodu" (jak mawiał Sławomir Mrożek)? Niekoniecznie! Jeśli wierzyć diagnozie Barbrooka, w polskiej przestrzeni nadziei dokonała się prosta, zupełnie nietwórcza wymiana jednego, przestarzałego modelu ustrojowego (socjalizmu wzorowanego na rozwiązaniach radzieckich) na drugi, niewiele mniej przestarzały model liberalnego kapitalizmu na modłę zachodnią. Jak pisze brytyjski politolog,

neoliberalne poglądy na gospodarkę nie były jedynie symbolem zerwania z biedniejącym imperium radzieckim, lecz także oznaką podporządkowania się amerykańskiemu postindustrialnemu wariantowi nowoczesności. Nowe elity „nowej Europy” popełniły błąd, zamieniając w istocie wyobrażoną przyszłość jednego zimnowojennego imperium na wyobrażoną przyszłość drugiego imperium $^{20}$.

Dla wielu przedsiębiorczych jednostek mogło to oznaczać perspektywę realnej i znaczącej poprawy sytuacji życiowej, i faktycznie wskutek neoliberalnych zmian ustrojowych w krótkim czasie wytworzyły się nowe elity biznesowe i finansowe. Lecz ogromnej części społeczeństwa ta zmiana nic nie przyniosła, poza czysto symboliczną zmianą fasady, za którą wszakże nadal trwały niejawne dla ogółu i daleko nie zawsze uczciwe rozgrywki, w wyniku których dokonywała się owa wymiana elit.

\footnotetext{
19 Tamże, 9.

20 Tamże.
} 


\section{Polska transformacja ustrojowa jako przestrzeń przemian nadziei istotnej}

Wiele wskazuje na to, że równolegle z wymianą elit w tym samym czasie dokonywała się niepostrzeżenie, bez głośnych deklaracji i ideowych manifestów, wymiana aksjologii. Powoli zmieniało się to, co Józef Tischner zwykł nazywać „nadzieją istotną". Spójrzmy na ów proces z perspektywy autora Etyki solidarności po latach. Z wyraźnie wyczuwalnym smutkiem i rozczarowaniem pisze tam Tischner o destrukcji idei międzyludzkiej solidarności, w miejsce której coraz powszechniej i coraz bezwzględniej pojawia się duch rywalizacji, walki, konfliktu partykularnych interesów, bronionych z egoistyczną zawziętością przez uczestników życia publicznego. Autor omawianych tu analiz doszukuje się źródeł rozpadu solidarnościowego etosu w jakimś bliżej niezdefiniowanym „mankamencie rozumu”"21, a jego skutki widzi następująco:

Chciałbym przyjrzeć się nieco bliżej kierunkom rozpadu pierwotnej idei solidarności. [...] Naszym problemem jest konflikt na poziomie ideologii lub raczej etycznej samowiedzy społecznej. W konflikcie tym ukazuje się zagadkowa twarz historii. Może jednak jeszcze wyraźniej ukazują się dramaty ludzkie, w których z niewiadomych często przyczyn przyjaciel staje naprzeciw przyjaciela, brat przeciwstawia się bratu ${ }^{22}$.

O rozczarowaniu spowodowanym faktem, że skutki wielkiej ustrojowej przemiany okazały się boleśnie odmienne od oczekiwanych, pisze także Richard Barbrook:

Dwie dekady [po roku 1989 - K. T. W.] uczestnicy konferencji Solidarity/solidarities $[\ldots] \mathrm{w}$ sali wykładowej londyńskiego University College, poświęconej wschodnioeuropejskim rewolucjom [...] stanęli w obliczu trudnego zadania wyjaśnienia, jak doszło do tego, co jeden z mówców określił mianem „podwójnego rozczarowania”. Radykałowie z Zachodu oczekiwali, że upadek stalinizmu doprowadzi do rozkwitu prawdziwego socjalizmu we wschodniej Europie - tymczasem ujrzeli, jak kraje „nowej Europy” wprowadzają brutalny

\footnotetext{
21 Tischner, „Etyka solidarności po latach”, 249.

22 Tamże, 250.
} 
neoliberalizm. Wczorajsi opozycjoniści myśleli z kolei, że gospodarka rynkowa oznacza szybki dobrobyt - miast tego nastąpiło pogłębienie podziałów między biednymi a bogatymi. [...] Odrzuciwszy nieudany eksperyment społeczny radzieckich komunistów, rozsądni i mądrzy ludzie przystali ochoczo na nowy eksperyment: na neoliberalizm w amerykańskim stylu. A przecież były inne opcje $^{23}$.

Nowy porządek społeczny i polityczny, wyczekiwany z wielką nadzieją i budowany początkowo $\mathrm{z}$ wielkim entuzjazmem, nie przyniósł jednak w rezultacie ani ucieleśnienia pięknej idei powszechnego braterstwa solidarnych podmiotów, ani masowej poprawy jakości i poziomu codziennego życia. Przyniósł natomiast cały szereg nowych, wcześniej nieznanych trudności i przeszkód, na czele z utratą stabilizacji życiowej i zanikiem poczucia bezpieczeństwa. Barbrook komentuje ironicznie: ,jeden z polskich słuchaczy westchnął z żalem podczas dyskusji, że on i jego rodacy korzystają teraz z największego z europejskich przywilejów: z możliwości publicznego uskarżania się na wszystko i wszystkich" ${ }^{24}$. Czy w tej sytuacji można się dziwić, że obok wciąż trwających zmagań o nową tożsamość, które dostrzega i wnikliwie opisuje Tischner w dalszym ciągu swego studium „Etyka solidarności po latach”25, zaczyna się pojawiać tęsknota za „socjalistycznym klientyzmem"?

\section{Faustyczne oblicze homo sovieticus: „Komuno, wróć, jesteś piękna..."}

Przy wszystkich swych wadach i słabościach system społeczny panujący w PRL i w innych krajach tak zwanej demokracji ludowej zapewniał swym obywatelom stosunkowo duże poczucie bezpieczeństwa oraz wysoki stopień przewidywalności perspektyw życiowych. Mowa tu, rzecz jasna, o końcowym okresie formacji socjalistycznej, zwanym „socjalizmem z ludzką twarzą" (określenie to zostało ukute przez partyjnych ideologów z ekipy Edwarda Gierka). Wczesnej, stalinowskiej fazie „dyktatury proletariatu" można byłoby przypisać wszystko, tylko nie kształtowanie poczucia bezpieczeństwa i klimat stabilizacji. W tamtym mrocznym okresie dziejów

\footnotetext{
${ }^{23}$ Barbrook, Przyszłości, 7-12.

${ }^{24}$ Tamże, 8.

${ }_{25}$ Zob. Tischner, „Etyka solidarności po latach”, 253-255.
} 
praktycznie każdy był narażony na możliwe represje, które spadały na ludzi często niespodziewanie i bez ostrzeżenia, z powodów nierzadko dalekich od racjonalnej przewidywalności.

Pod tym względem sytuacja znacznie się poprawiła i unormowała w latach siedemdziesiątych (z wyjątkiem ostatniej, konwulsyjnej próby ocalenia własnej pozycji przez komunistyczny establishment PRL w postaci stanu wojennego, wprowadzonego w grudniu 1981 roku, zawieszonego po roku obowiązywania, a formalnie zniesionego 22 lipca 1983 roku). Nie oznacza to $\mathrm{w}$ żadnym razie, by w owym późnym, zreformowanym i zhumanizowanym systemie poststalinowskim nie istniał aparat represji wraz z tajną policją i licznym gronem jej (nie zawsze w pełni dobrowolnych) współpracowników. Do samego końca trwania socjalistycznej Rzeczypospolitej Ludowej zdarzały się akty brutalnego, państwowego terroru oraz trwały systemowe działania tak zwanych organów bezpieczeństwa, wymierzone przeciw grupom i jednostkom, zdaniem władz stanowiącym zagrożenie dla porządku ustrojowego ${ }^{26}$. Sytuacja poprawiła się jednak o tyle, że po pierwsze, znacznie zmniejszyła się skala milicyjnego terroru, zwłaszcza w porównaniu z okresem sprzed 1956 roku, po drugie zaś w znacznym stopniu zredukowane zostały akty ślepej przemocy, skierowanej przeciwko przypadkowym ofiarom, których przewinienia wobec aparatu władzy były minimalne lub zgoła iluzoryczne.

Status quo późnego i schyłkowego socjalizmu można by określić jako rodzaj niepisanej (i nie zawsze, niestety, przestrzeganej) umowy między władzą a obywatelami. W rezultacie swoistej gry politycznej, prowadzonej przez dwie nierównoważne strony ${ }^{27}$, powstał stopniowo system, który wprawdzie zabierał lub ograniczał czy też reglamentował wolność (mówiąc nieco ironicznie, obywatele otrzymywali wolność w leasing od władzy państwowej), ale w zamian dawał poczucie bezpieczeństwa na co dzień - na dziś i na ju-

26 Zob. Zbigniew Jerzy Hirsz, Historia polityczna Polski 1939-1993 (Białystok: PPUH Book House, 1996), 191-226 (cz. II, rozdz. 4: „Mechanizmy zastraszania i zniewalania”).

27 „Był to klasyczny konflikt pomiędzy stronami, które łączy stosunek nadrzędność podrzędność" [Postawy i wartości w okresie konfliktu społecznego, red. Stefania Dzięcielska-Machnikowska (Warszawa: KAW 1985), 15]. Adam Michnik zauważa w 1995 roku: „mówię z perspektywy zarodków niezależnego społeczeństwa, którego wykluwanie się obserwowałem gdzieś od 1964 roku [...] zdawałem sobie sprawę, że przez te wszystkie lata tkamy skomplikowaną siatkę niezależności, którą tworzą [...] różne środowiska i inicjatywy. Komunizm mógł próbować to niszczyć metodą Hansa Franka - rozwałki, wywózki, obozy. Ale jeśli się na takie metody nie decydował, musiał się jakoś ze społeczeństwem układać" [Adam Michnik, Józef Tischner, Jacek Żakowski, Między Panem a Plebanem (Kraków: Znak 1995), 425]. 
tro. Obowiązywał dość stabilny system zatrudnienia, można było liczyć na pewne emerytury, nie było szokujących różnic w poziomie życia poszczególnych warstw społecznych. Odzwierciedla ów stan obiegowe powiedzenie z tamtych czasów: słynne „czy się stoi, czy się leży, dwa tysiące się należy”. Był to swego rodzaju deal obywatela $\mathrm{z}$ władzą. Można było jednostronnie zerwać tę umowę i zrzec się gwarantowanego bezpieczeństwa (gwarantowanego, co prawda, za niebłahą cenę - cenę konformizmu lub jeszcze wyższą: wyrzeczenia się własnych, rzeczywistych ideałów na rzecz cynicznej pozy). $\mathrm{Ci}$, co się zrzekli, mieli jednak pełną świadomość, na jakie konsekwencje się narażają, i faktycznie padali zazwyczaj ofiarą represji.

Funkcjonowanie tego systemu, a także konsekwencje nieposłuszeństwa, były w dużej mierze (choć nie do końca) przewidywalne; przynajmniej w okresie późnego PRL. Zdecydowana większość społeczeństwa akceptowała ten model stosunków obywatele-władza; nawet demokratyczni opozycjoniści w jakiejś mierze aprobowali, a przynajmniej rozumieli prawo władzy do represji ${ }^{28}$. Wiadomo było bowiem, że komunistyczny system władzy może przetrwać tylko oparty na przemocy, ponieważ dobrowolnie naród nigdy by go nie zaakceptował. Pamiętano, że nowy ustrój od początku był narzucany siłą i podstępem, włączając w to pamiętne fałszerstwo wyborcze w styczniu 1947 roku. Ponadto ustrój, oparty na marksistowsko-leninowskiej ideologii, kojarzył się jednoznacznie z narzuconą hegemonią Związku Radzieckiego (nazywanego w języku ulicy Wielkim Czerwonym Bratem), był więc obcy kulturowo i aksjologicznie - zwłaszcza z powodu swego agresywnego ateizmu, jaskrawo sprzecznego z polską tradycją narodową.

Równocześnie jednak panowało dość powszechne przekonanie o „fatalizmie geopolitycznym". Doświadczenia drugiej wojny światowej nie pozostawiały złudzeń: w wyniku rozstrzygnięć między wielkimi światowymi mocarstwami Polska na długie lata utraciła szansę realizacji własnej, autonomicznej polityki opartej na narodowej racji stanu. Z całkowitą obojętnością wobec woli i oczekiwań polskiego społeczeństwa zostaliśmy wcieleni w obręb przymusowej wspólnoty krajów tak zwanego obozu demokracji ludowej, pod niekwestionowanym i nieuniknionym, a niekiedy mocno uciążliwym,

28 „Istota rzeczy była taka, że w Polsce trwała polityczna walka. Siedzieliśmy w więzieniu nie dlatego, że powinęła nam się noga i złapano nas podczas skoku na kiosk Ruchu, tylko dlatego, że dokonaliśmy pewnego życiowego wyboru, którego można było nie podzielać, ale który wypadało uszanować" - wspomina Michnik w rozmowie z Tischnerem i Żakowskim, na co Tischner dodaje: „Pokazywaliście, jak wygląda polska wolność, i w tym sensie byliście potrzebni za tymi kratami” [Tamże, 432]. 
przywództwem Kraju Rad. Każdy Polak wiedział, że z Moskwą nie wygramy, a Zachód pochłonięty własnymi sprawami nie ma żadnego interesu ani woli politycznej, by wspierać dążenia niepodległościowe ludów spoza żelaznej kurtyny. Trzeba było się nauczyć żyć - jak się wówczas mówiło (rzecz jasna, po cichu i w zaufanym towarzystwie) - pod łapą Czerwonego Niedźwiedzia. Rozumiała to i władza, i zdecydowana większość narodu. Świadectwem powszechności postawy fatalistycznej rezygnacji może być wspomnienie o. Macieja Zięby OP, który lata swego dorastania określa jako

czas, gdy prawie cały świat mówił do nas: Nie bądź naiwniakiem, nie bądź idealistą, wtop się w ten system, nie bądź donkiszotem - Jałty nie zmienisz, niemieckiej Realpolitik nie przetransformujesz, francuski pragmatyzm nigdy nie pozwoli umierać za Gdańsk, tysięcy głowic nuklearnych też nie rozbroisz, za duży wiatr na twoją wełnę. A jeżeli nie będziesz pokorny, to wcześniej czy później będziesz miał na karku SB, Stasi czy inne KGB, które zniszczy ci życie ${ }^{29}$.

W przeprowadzonym na początku lat osiemdziesiątych przez Teresę Torańską wywiadzie jeden z czołowych przywódców PRL w pierwszym okresie rządów partii komunistycznej, Jakub Berman, tak opisywał stosunek władz polskich do narzuconej sytuacji geopolitycznej:

myślenie, że my sobie w kąciku usiądziemy, do jednych się trochę uśmiechniemy, do drugich się uśmiechniemy, jest głupotą, świadczy o nieznajomości geografii i elementarnych zasad polityki. Polska może być tylko albo prosowiecka, albo proamerykańska, nie ma innej możliwości. Polski nie można wyrwać z bloku sowieckiego. Bo co, wyrwać i gdzie ją umieścić? Na księżycu? Na księżyc się z nią wybrać? Polska leży na drodze między Związkiem Radzieckim a Europą Zachodnią i jej pozycja jest jasna: albo-albo, nie ma kolorów pośrednich, bo Polska nie może wisieć w powietrzu. Obiektywna rzeczywistość jest więc taka, że albo Ameryce uda się wywołać tutaj ferment taki, który nas obali i wtedy naturalnie nastąpi interwencja, bo wymagają tego nadrzędne interesy Związku Radzieckiego [...], albo cały obóz poniesie klęskę i Polska stanie się Księstwem Warszawskim, albo wybuchnie trzecia wojna światowa ${ }^{30}$.

${ }^{29}$ Maciej Zięba, „Wstęp”, w: Władysław Bartoszewski, Warto być przyzwoitym (Poznań: W Drodze, 2005), 6.

30 Teresa Torańska, Oni (Warszawa: Aneks, 1985), 356. 


\section{6. „Siedź cicho i rób swoje” - zasada politycznej mimikry jako alternatywa dla walki o wolność}

Świadomość nieustannego niebezpieczeństwa konfrontacji z jednym z zarysowanych przez Bermana scenariuszy budziła grozę. Trzeba było jednak jakoś żyć z tą świadomością. Józef Tischner twierdzi, że funkcjonariusze władzy państwowej uczynili z lęku przed konsekwencjami zbiorowego nieposłuszeństwa parasol dla własnych, koniunkturalnych poczynań, w tym dla permanentnego okłamywania obywateli: „Mamy utrwalone skojarzenia lękowe. Reszta jest zdumiewająco logiczna. Jeśli się nie chce przelewu krwi, jeśli się chce uratować lud, trzeba kłamać. Kłamstwo jest koniecznością życia [...] nie przestaje być złem, ale jawi się jako mniejsze zło. Racją polityki kłamstwa staje się zasada mniejszego zła"31. Nie można wykluczyć, że na mniejszą, indywidualną skalę podobną ,mikropolitykę” uprawiali również obywatele. Poza nielicznymi wyjątkami, większość godziła się podporządkować prawu mimikry, które tylko krok dzieli od kłamstwa: nie drażnić władzy, udawać lojalnych poddanych, a po cichu robić swoje. Nieprzypadkowo satyryczna piosenka Wojciecha Młynarskiego z 1986 roku, z powtarzającym się refrenem: „Róbmy swoje! / Pewne jest to jedno, że / Róbmy swoje! / / Póki jeszcze ciut się chce", stała się przez ostatnie lata PRL (obok songu Jana Pietrzaka „Aby Polska była Polską”) niemalże nieformalnym alternatywnym hymnem Polski.

W realizację i utrzymanie tak zarysowanego status quo zaangażowana była wolność poszczególnych obywateli. Niekiedy (można chyba powiedzieć: przeważnie) przybierała formę dobrowolnego samoograniczenia po to, by skutecznie chronić imponderabilia, to znaczy, przede wszystkim względnie samodzielny byt narodu na względnie bezpiecznych obrzeżach Wschodniego Imperium. Zawsze jednak istniał pewien margines - raz mniejszy, raz większy - dla wolności heroicznej. Istniała bowiem wąska, lecz znacząca elita ludzi, którym samoograniczająca się wolność nie wystarczała $^{32}$. Woleli oni narazić się na wieloletnią, całkowitą utratę wolności-

31 Józef Tischner, „Kłamstwo polityczne”, w: Józef Tischner, Polski mlyn (Kraków: Nasza Przeszłość, 1991), 123-124.

32 Jako przykład niezłomnego bojownika o wspólną wolność może niewątpliwie posłużyć Władysław Bartoszewski. W poświęconym mu szkicu biograficznym Andrzej Friszke cytuje następujące słowa, wygłoszone na spotkaniu Seminarium Oświęcimskiego w 1974 roku: „,musimy działać cierpliwie, nie pospiesznie, ale zdecydowanie i konsekwentnie. Więcej: musimy 
może nawet życia, bo i takiego scenariusza nie można było wykluczyć - po to, by przez krótką chwilę móc się nią cieszyć w pełni. W takich przypadkach wolność przybierała formę obywatelskiego sprzeciwu, czyli głośnego mówienia „nie” władzy.

\section{Przelom 1989 roku i nowa konfiguracja przestrzeni wolności}

Po ponad 40 latach sprawowania władzy w Polsce przez PZPR nadszedł rok 1989, a wraz z nim - jego konsekwencje w postaci transformacji ustrojowej. Jedną z tych konsekwencji była szybka i radykalna zmiana konfiguracji przestrzeni wolności. Do tej pory wyglądała ona z grubsza następująco: po dwóch przeciwległych stronach stały: opresyjne państwo z jego aparatem administracyjnym i kadrą wykonawczą oraz anonimowa rzesza obywateli o ściśle reglamentowanej przestrzeni indywidualnej wolności, której przekroczenie groziło mniej lub bardziej dotkliwymi represjami. Po czerwcowym przełomie 1989 państwo stopniowo przestało być represyjne, a nowo wybrane, demokratyczne władze zobowiązały się do gwarantowania i ochrony swobód obywateli w ramach wyznaczonych przez prawo. Nagle w obręb porządku życia publicznego została włączona zasada, o której wcześniej mało kto pamiętał: ,granicą mojej wolności jest wolność drugiego człowieka". Zasadę tę sformułował niegdyś Alexis de Tocqueville w następujących słowach: „Wolność człowieka kończy się tam, gdzie zaczyna się wolność drugiego człowieka" ${ }^{33}$. Nawiązując do niej, Józef Tischner pisał:

Granicą mojej wolności jest wolność drugiego człowieka. Nie jest zadaniem państwa wskazywanie tych wartości, którym obywatel winien się poddać -

mieć odwagę działać także i niepopularnie. Musimy być gotowi do ofiar [...] musimy być jako chrześcijanie gotowi także do wspólnych nadludzkich niemal wysiłków, aby osiągnąć nasz wspólny cel”, po czym warszawski historyk komentuje: „Słowa o potrzebie wysiłków i ofiar dotyczyły $[\ldots]$ nie tyle stosunków polsko-niemieckich, ile walki o poszerzenie ram wolności w Polsce. W kontakcie ze środowiskami organizującymi różne akcje sprzeciwu wobec władz PRL Bartoszewski pozostawał od lat” [Andrzej Friszke, „Władysław Bartoszewski - szkic portretu”, w: Bartoszewski, Warto, 30-31]. Jeszcze krótszą, lecz równie trafną charakterystykę Bartoszewskiego formułuje Maciej Zięba: ,więzień Auschwitz, AK-owiec ratujący Żydów i walczący w Powstaniu, u zarania PRL - młody opozycyjny polityk, a gdy tylko PRL podrosła - jej wieloletni więzień” [Zięba, „Wstęp”, 6].

${ }^{33}$ Alexis de Tocqueville, O demokracji w Ameryce (Warszawa: PIW, 1976). 
wolność „ku czemuś” jest indywidualną sprawą obywatela - zadaniem państwa jest jedynie stworzenie odpowiedniej przestrzeni społecznej, w której każdy może swobodnie urzeczywistniać siebie. Państwo otwiera przed każdym pole wolności, ale nie decyduje o tym, jak obywatel pole to uprawi ${ }^{34}$.

Poważnym problemem w realiach postkomunistycznej rzeczywistości stał się brak ,instrukcji obsługi” do nowego typu wolności - w jaki sposób i jakimi narzędziami uprawiać to pole, które nagle otworzyło przed nami ogrom nieprzeczuwanych wcześniej możliwości? Polak ,urodzony w niewoli, okuty w powiciu" 35 nie miał się skąd nauczyć reguł życia w warunkach demokracji - rzeczywistej, a nie, jak dotychczas, „ludowej” czy „socjalistycznej", czyli pozornej. W poprzednim systemie indywidualna walka obywatela o poszerzenie granic wolności równocześnie służyła innym obywatelom, gdyż wspólnym przeciwnikiem w tej walce był aparat państwowy, który równomiernie uciskał wszystkich. W nowej rzeczywistości nastąpiła istotna zmiana: kiedy ktoś poszerza własną wolność, tym samym równocześnie zabiera ją lub ogranicza komuś innemu, słabszemu (można to dostrzec między innymi na przykładzie relacji między pracodawcą a pracownikami czy też w przypadku dyskryminacji prawnej takiej czy innej mniejszości, powstałej w wyniku demokratycznie uchwalonej woli większości). Owszem, istniała w III RP „kuźnia kadr” wolności: nieliczna, lecz zahartowana w walce z przeciwnościami awangarda narodu - dawni działacze opozycji demokratycznej, weterani obywatelskiego sprzeciwu. Logika dziejów nakazywała, by to oni - już wychowani do wolności - przejęli ster rządów i stworzyli warunki do wolności dla pozostałej części społeczeństwa. Mogło się to jednak stać wyłącznie na nowych zasadach, to znaczy za zgodą ogółu wyrażoną w demokratycznych wyborach. Jak się okazało, tej zgody wystarczyło na jedną kadencję, w dodatku niepełną, po czym do władzy wróciła lewica ${ }^{36}$. Dlaczego tak się stało? Czy przypadkiem nie ze względu na większe, niż

34 Tischner, Nieszczęsny, 136.

${ }^{35}$ Adam Mickiewicz, Pan Tadeusz (Paryż: A. Pinard,1834), 213.

${ }^{36}$ Pierwsze po drugiej wojnie światowej w pełni demokratyczne i wolne wybory parlamentarne w Polsce odbyły się 27 października 1991 roku; przyniosły zwycięstwo ugrupowaniom postsolidarnościowym. Jednakże w wyniku kryzysu politycznego (wotum nieufności wobec rządu Hanny Suchockiej) w 1993 roku odbyły się kolejne, przedterminowe wybory, w których najwięcej mandatów zdobył lewicowy SLD, a na czele rządu stanął zrazu Waldemar Pawlak z PSL, zastąpiony na tym stanowisku w 1995 przez Józefa Oleksego z SLD, a następnie Włodzimierza Cimoszewicza (również SLD) [Zob. Hirsz, Historia, 386-388]. 
przypuszczali liderzy transformacji, stężenie pierwiastka homo sovieticus w społecznym krwiobiegu?

\section{Józef Tischner - obserwator polskich duchowych zmagań - i jego diagnozy postaw wobec wolności}

Kiedy w czasach PRL działacze opozycyjni narażali własną wolność, bezpieczeństwo i karierę, czynili to w przekonaniu, że działają nie we własnym interesie, lecz w imieniu całego narodu. Czy to przekonanie było słuszne? Trudno mieć pewność w tym względzie. Nikt nie prowadził szeroko zakrojonych badań w celu zweryfikowania owej hipotezy, a głos „,szarego obywatela" nie był słyszalny w przestrzeni publicznej, ponieważ praktycznie nie istniały kanały „poziomej” komunikacji między obywatelami oraz na linii obywatel-władza (poza tymi kontrolowanymi przez państwo, w rodzaju przysłowiowych „listów do redakcji”, w których jednak nie wypowiadało się szczerych opinii). Władza miała monopol na dyskurs publiczny, w którym było bardzo niewiele miejsca na prawdę ${ }^{37}$. W tej sytuacji bezcennym „laboratorium socjologicznym” okazał się... konfesjonał. Dzięki „wieściom ze słuchanicy" ${ }^{\prime 8}$ Józef Tischner uzyskał dużo bardziej wiarygodny obraz nastrojów społecznych niż władza i opozycja razem wzięte.

Tischnerowskie dyżury w konfesjonale (lub, mówiąc po góralsku, „posiady w słuchanicy") przyniosły kolejno trzy ważne diagnozy: chochoł sar-

37 „Do 1989 r. [...] proces komunikacji władzy ze społeczeństwem [...] miał w zasadzie charakter jednostronny. Wyraźnie dominował monolog nad dialogiem. W układzie monopolu informacyjnego miejsce centralne i decydujące zajmował nadawca. Był on swoistym «gospodarzem języka». To on ustalał znaczenia i nazwy. Jego oceny nie podlegały zakwestionowaniu. Odbiorca pozostawał całkowicie bierny. Dopuszczany był do głosu tylko wtedy, gdy mówił takim samym szablonowym językiem i gdy jego wypowiedź przeszła przez sito cenzorskie. [...] Należy zwrócić tu uwagę na jeszcze jeden fakt dotyczący samej formy wypowiedzi politycznej okresu PRL-u. Otóż niezależnie od nadawcy komunikat pozostawał ten sam wygłoszony w «jedynie słusznym języku propagandy politycznej»” [Michał Bancerz, „Język polityki i polityków - wczoraj i dziś”, Pisma Humanistyczne 5 (2003): 173].

38 „Słuchanica, czyli konfesjonał. Tam się chodzimy wysłuchać, czyli wyspowiadać. Ksiądz nas słucha - albo zamyka uszy na wewnętrzne klapki. [...] Ksiądz Tischner był księdzem wyrozumiałym, bo można było [...] opowiedzieć mu swoje biedy i sekrety. [...] «Tiśnier wie» - mawiano z uznaniem” - pisze Wanda Czubernatowa we wstępie do książki wydanej wspólnie z Józefem Tischnerem: Wieści ze stuchanicy [(Kraków: Znak, 2001), 5]. 
mackiej melancholii ${ }^{39}$, ludzie z kryjówek ${ }^{40}$, homo sovieticus ${ }^{41}$. Nie miejsce tu, by je omawiać. Warto podkreślić jedno: przeciętny penitent - jak się okazało, sądząc po treści Tischnerowskich diagnoz - prezentował raczej niewielką gotowość do heroicznej walki o wolność. Często wybieranym sposobem przetrwania było budowanie takiej wersji imaginarium społecznego, która $\mathrm{z}$ jednej strony kontestowała oficjalną, państwowotwórczą nowomowę, ale z drugiej - usprawiedliwiała własną bierność i kunktatorstwo. Dziś możemy twierdzić, że pod presją wydarzeń historycznych ta minimalistyczna strategia się nie sprawdziła, ponieważ heroiczna awangarda narodu wywalczyła dla nas więcej wolności, niż śniło się naszym filozofom. Ale do efektywnej i właściwej eksploatacji tej - nagle poszerzonej-przestrzeni wolności trzeba było dorosnąć szybko i niebezboleśnie. Taka jest geneza książki Nieszczęsny dar wolności. Okazał się on „nieszczęsny” co najmniej z dwóch powodów: u jednej części społeczeństwa wzbudzał lęk i skłaniał do szukania nowych kryjówek (jak na przykład wizja Kościoła jako „oblężonej twierdzy”, wokół której pleni się szatański świat laickiego liberalizmu), u drugiej - wyzwolił inicjatywę wzięcia swoich spraw we własne ręce w sposób, który zaowocował dzikim kapitalizmem i szybko rosnącym rozwarstwieniem ekonomicznym. W rezultacie działania owego mechanizmu społecznego jedni zostawali coraz bardziej w tyle, drudzy stopniowo uwłaszczali i zawłaszczali Polskę.

\section{Idea solidarności i jej stopniowa atrofia}

Okres transformacji ustrojowej okazał się także prawdziwym, niezwykle trudnym sprawdzianem dla idei solidarności. Stawało się widoczne, że łatwiej było niegdyś skupić pod sztandarami Solidarności ludzi uciskanych i opuszczonych, dla których ten ruch był szansą rozwoju i awansu społeczne$\mathrm{go}^{42}$, niż dziś - ludzi sytych i zadowolonych z siebie, dumnych z odniesione-

39 Józef Tischner, „Chochoł sarmackiej melancholii”, w: Józef Tischner, Świat ludzkiej nadziei (Kraków: Znak, 1975), 15-28; pierwodruk w: Znak 198 (1970): 1243-1254.

40 Józef Tischner, „Ludzie z kryjówek”, w: Józef Tischner, Myślenie wedlug wartości (Kraków: Znak, 1982), 415-433, pierwodruk w: Znak 283 (1978), 57-72.

${ }^{41}$ Józef Tischner, „Homo sovieticus”, pierwodruk: Gazeta Wyborcza 10 (1991), dodatek: Gazeta Świąteczna, 5.

${ }^{42} \mathrm{~W}$ „Etyce solidarności po latach” Tischner przytacza następującą diagnozę ówczesnego ruchu społecznego: „Jest ruchem bezbronnych, ruchem narodu, który wbrew totalitarnej opresji odzyskuje swą tożsamość, przełamuje barierę niemożności i strachu, odbudowuje wewnętrzne więzi. „Solidarność” jest ruchem wszystkich warstw społecznych, ruchem robotników i księży, 
go sukcesu, których idea solidarności przymuszała do podzielenia się dopiero co zdobytymi dobrami. To zrozumiałe, ale mało pocieszające; świadczy bowiem o tym, jakie są nasze faktyczne preferencje. Solidarność z tymi, którzy mają mniej dóbr materialnych i mniej szans życiowych niż my, okazuje się znacznie trudniejsza do osiągnięcia niż solidarność przeciw tym, którzy mieli więcej władzy politycznej i swobody działania niż my - niestety, wbrew temu, co mówił Tischner w pamiętnym kazaniu w Katedrze Wawelskiej 19 października 1980 roku: „Solidarność, ta zrodzona z kart i ducha Ewangelii, nie potrzebuje wroga lub przeciwnika, aby się umacniać i rozwijać. Ona się zwraca do wszystkich, a nie przeciwko komukolwiek"43.

Takiej solidarności już nie ma. Została wyparta przez proces, który Tischner charakteryzuje następująco:

Oto ewolucja naszego świata. Widzimy ten świat, jest dokładnie podzielony [...]. Jest jakiś moment w rozwoju świadomości moralnej, gdy moralność przeradza się w moralizm, a moralizm staje się antyhumanizmem. Zasada moralna nie służy już rozwojowi człowieka, ale jego poniżeniu. „Złem”, które zasada opisuje, nie jest już oddalające się coraz bardziej zło komunizmu, ale domniemane zło kandydata do tego samego stanowiska politycznego ${ }^{44}$.

Przyczyna rozpadu pierwotnej idei solidarności może być tylko jedna: otwarte przez posttransformacyjne państwo „pole wolności” zostało zagospodarowane $\mathrm{w}$ taki sposób, jaki ogół społeczeństwa uznał za właściwy. Widocznie - jako zbiorowy suweren, który przejął w swe ręce wspólny los - nie dorośliśmy jeszcze do takiego etosu solidarności, jakiego obraz kreślił przed nami Tischner na przełomie 1980 i 1981 roku. Ci, którzy byli już wtedy na świecie, pamiętają, że żyliśmy przez krótką chwilę w pięknym, romantycznym złudzeniu, że stać nas na wielkoduszność i wspaniałomyślność, że nasza duchowa dzielność i wewnętrzna uroda potrafi zatryumfować nad małostkowym egoizmem - zarówno indywidualnym, jak i zbiorowym. Nie zatryumfowała. Zwyciężył duch Kargula i Pawlaka, tradycyjny etos odwiecznego, nigdy się niekończącego sporu o miedzę, o płot, o to, by sprawiedliwość zawsze była po naszej, a nie po ich stronie.

rolników i intelektualistów, katolików i niewierzących, ruchem, który ogarnął cały naród, wytrzymał represje wojskowej dyktatury, zbudował niezależny obieg informacji i refleksji” [Tischner, „Etyka solidarności po latach”, 256].

${ }^{43}$ Tischner, Etyka solidarności, 7.

44 Tischner, „Etyka solidarności po latach”, 257. 


\section{Między heroizmem a konformizmem - dziś}

Nowa konfiguracja przestrzeni wolności - otwarte pole, o którym pisał Józef Tischner w Nieszczęsnym darze wolności - rodzi nowe wyzwania. O ile nadal nie brak podstaw, by twierdzić, że pole to rozpościera się między heroizmem a konformizmem, o tyle nie można już przykładać do tych pojęć dawnej miary, wywiedzionej z poprzedniej epoki. Zupełnie inaczej wygląda dziś konformizm, zupełnie do czego innego wzywa dziś heroizm. Konformista - zgodnie z prawem mimikry, pod tym względem sytuacja się nie zmieniła - ochoczo wtapia się w tłum, z zapałem dostraja swój głos do chóru powtarzającego unisono propagandowe slogany i czuje dumę, że stał się cząstką zbiorowej duszy najpiękniejszego na świecie narodu. Rozwiązanie łatwe i satysfakcjonujące. Zwłaszcza że treści współczesnej państwowotwórczej narracji są dziś nieskończenie bliższe gustom Polaka niż to, czym karmiła nas propaganda okresu potocznie zwanego „słusznie minionym”.

A co z heroizmem? Niewątpliwie tu również nastąpiła radykalna zmiana - chociażby pod tym względem, że dziś bycie po stronie opozycji nie daje już poczucia jednoznacznej moralnej wyższości (jak w czasach sprzed przełomu). Nie ma dziś czarno-białego podziału na „my” i „oni” (choć niektórzy wciąż chcieliby go widzieć). Nie ma też bezpośredniego zagrożenia wolności ze strony władzy (choć są tacy, którzy tak twierdzą). Problem dla wielu trudny do zrozumienia i zaakceptowania - tkwi w tym, że obecnie najważniejsze zmagania toczą się na innym poziomie; niewidocznym na scenie narodowego dramatu, w którym tak chętnie szukamy dla siebie eksponowanych ról. Walka toczy się w każdym z nas: o to, byśmy starali się przezwyciężać w sobie pokusy łatwego, egoistycznego, pozbawionego troski o innych korzystania z coraz powszechniej dostępnych zasobów urynkowionego świata totalnej konsumpcji - to raz, a dwa - o to, byśmy nie ulegli równie trudnej do odparcia pokusie „moralizatorstwa, które stało się antyhumanizmem". Owszem, to cudowne uczucie - mieć rację, być moralnie doskonałym i z wyżyn własnej doskonałości ze zrozumiałym oburzeniem potępiać i piętnować występnych zdrajców, nosicieli wszelkiego zła tego świata. Tylko czy naprawdę mamy do tego prawo? Czy rzeczywiście ludzki ród dzieli się na dwie, ostro od siebie odseparowane i dające się z dziecinną łatwością zidentyfikować kategorie - bohaterów i zdrajców? Czy heroiczna wolność polega dziś na tym, by samemu sytuując się z błogą moralną pewnością w grupie bohaterów, rzucać publicznie gromkie oskarżenia na wszystkich, których z równą pewnością zaliczamy do tej drugiej kategorii? 


\section{W poszukiwaniu aktualnych wzorców chrześcijańskiego heroizmu}

Jest jeszcze jeden teren walki o właściwe zagospodarowanie otwartego dziś przed nami pola wolności. Dotyczy tych, którzy czują żywą więź z Kościołem i pragną podążać za jego nauczaniem. Warunkiem wejścia na drogę heroicznej wolności, rozumianej po chrześcijańsku, jest to, byśmy odzyskali słuch na Ewangelię i zrozumieli, że jesteśmy „zawierzeni Słowu"45. Wiara rodzi się ze słuchania, a jakość naszej wiary zależy od jakości naszego słuchania ${ }^{46}$. Jan Patočka twierdził, że Europa jeszcze nie stała się naprawdę chrześcijańska, gdyż chrześcijańska wizja człowieka i świata nie została jeszcze do końca przemyślana ${ }^{47}$ (pytanie, czy kiedykolwiek zostanie). A Polska? Urodzona w niewielkiej miejscowości Rzeniszów, w gminie Koziegłowy, utalentowana polska pisarka Wioletta Grzegorzewska twierdzi, że w Polakach zawiera się wciąż jeszcze więcej pogaństwa niż katolicyzmu. Wspominając swoje dzieciństwo na wsi nieopodal Częstochowy, pisze:

uosobieniem pogańskości chłopskiej był dla mnie bebok [...]. Ludzie wierzyli w moc roślin. No przecież polscy chłopi, między którymi żyłam osiemnaście lat, nie myśleli po katolicku. Nikt mnie o tym nie przekona. Żyli zgodnie z katolicką tradycją obrzędową i kalendarzem, ale ich myślenie było raczej panteistyczne. Tysiąc lat od chrztu Polski nie wystarczyło, aby kulturę całkowicie pozbawić jej słowiańskości i prastarych obrządków [... $]^{48}$.

To oczywiście gruba przesada, ale gdybyśmy na chwilę założyli, że miarą naszej katolickiej wiary nie jest stosunek do beboków i innych zabobonów, lecz ewangeliczna solidarność z ubogimi, cierpiącymi, potrzebującymi; tymi, od których mamy o wiele, wiele więcej, i wcale nie z powodu naszych zasług - to jaką wielkość zmierzymy za pomocą tej miary? Jeśli podążymy drogą systematycznego wyostrzania naszego słuchu na słowa Ewangelii, to zapewne znajdziemy jeszcze niejedną taką miarę, której wskazania nie będą dla nas pochlebne. Tu właśnie - w obszarze słuchania i podążania za

${ }^{45}$ Grzegorz Ryś, Moc wiary (Kraków: WAM, 2017), 42.

46 Zob. Józef Tischner, Zrozumieć własną wiarę (Kraków: Znak, 2012), 41.

${ }^{47}$ Zob. Jan Patočka, Eseje heretyckie z filozofii dziejów (Warszawa: Fundacja Aletheia, 1998), 147.

48 Wioletta Grzegorzewska, „Kompleks polski”, Tygodnik Powszechny 41 (2017): 60. 
usłyszanym słowem - upatrywałbym dzisiejsze wzorce chrześcijańskiego heroizmu. Wyostrzyć słuch - to pozwolić Duchowi Świętemu przemówić do nas, pamiętając o tym, co mówił Joseph Ratzinger: „Boży Duch musi wciąż na nowo wyzwalać nas od ograniczeń, jakie stawiamy Jego działaniu"49. W tym samym tekście znalazły się jeszcze następujące słowa: „Wolność ludzi może się realizować tylko przez współgranie i wzajemne przyporządkowanie wolności poszczególnych jednostek [...], jeśli każdy myśli tylko o własnej wolności, wtedy niszczymy się wzajemnie" 50 .

\section{Zakończenie}

Wolność to wartość szczególnie droga sercom Polaków. Ci, którzy walczyli o naszą i waszą wolność, zajmują specjalne miejsce w panteonie bohaterów narodowych, a czasy niewoli bądź ograniczonej wolności wspominane są bardzo często w polskim dziejopisarstwie i literaturze. Nie byłoby jednak dobrze, gdyby temat wolności pojawiał się wyłącznie w historyczno-martyrologicznym kontekście. Wolność jest darem i zadaniem każdego pokolenia - nie tylko tych niegdyś o nią walczących, ale także tych dziś żyjących i tych nadchodzących po nas. Nie ma już wśród nas księdza Tischnera, po którym moglibyśmy - gdyby żył - zasadnie oczekiwać, że po książce Zrozumieć własna wiarę napisze jeszcze jedną: Zrozumieć własna wolność. Pozostawił nam jednak szereg wskazówek; niektóre z nich zostały ukazane w niniejszym tekście. Mamy niekwestionowane prawo do własnego, samodzielnego zgłębiania dalej owego problemu i praktykowania wolności wedle tych wzorców, które sami sobie wypracujemy. Oby ta praca intelektu, ducha i woli przyniosła efekty na miarę nadziei i oczekiwań tego, który na progu wolności uczył nas idei etyki solidarności.

\section{Spaces of Freedom: Between Heroism and Conformity (Summary)}

The experience of freedom can involve various life situations. According to $\mathrm{J}$. Tischner, the basic type of experience of freedom is a gradual liberation from limitations. Such has been the collective experience of Polish society during the period

\footnotetext{
49 Joseph Ratzinger, Głód Boga (Kraków: WAM, 2016), 109.

50 Tamże, 110.
} 
of transformation. The first trend of changes consisted of the gradual reconstruction of the political system aiming at the extension of the area of citizens' freedom. The second one involved a slow remodeling of consciousness. One has to mature to freedom in order to be able to use opportunities offered by it. The article is an attempt to analyze the relations and tensions between those two ways of building the space of freedom. Within the analysis the changes in the way of understanding two extreme approaches to exploitation of freedom - heroism and conformity.

Keywords: freedom; liberation; heroism; conformity; transformation.

\section{Przestrzenie wolności: między heroizmem a konformizmem (Streszczenie)}

Doświadczenie wolności może wiązać się z różnymi sytuacjami życiowymi. Zdaniem J. Tischnera podstawowym rodzajem doświadczenia wolności jest stopniowe wyzwalanie się spod ograniczeń. Takie doświadczenie stało się zbiorowym udziałem polskiego społeczeństwa w okresie transformacji. Pierwszy nurt przemian polegał na stopniowej przebudowie ram ustrojowych $\mathrm{w}$ kierunku poszerzania przestrzeni wolności obywateli. Drugi wiązał się z powolną przebudową świadomości. Do wolności trzeba bowiem dojrzeć, by móc korzystać z oferowanych przez nią możliwości. Artykuł jest próbą analizy relacji i napięć między tymi dwiema ścieżkami budowania przestrzeni wolności. W ramach tej analizy ukazano przemiany sposobu rozumienia dwóch skrajnych podejść do eksploatacji wolności - heroizmu i konformizmu.

Słowa kluczowe: wolność; wyzwolenie; heroizm; konformizm; transformacja.

\section{Bibliografia}

Bancerz, Michał. „Język polityki i polityków - wczoraj i dziś”. Pisma Humanistyczne 5 (2003): 172-181.

Barbrook, Richard. Przyszłości wyobrażone. Od myślacej maszyny do globalnej wioski. Tłum. Jan Dzierzgowski. Warszawa: Muza S.A., 2009.

Bartoszewski, Władysław. Warto być przyzwoitym. Poznań: W Drodze, 2005.

Czubernatowa, Wanda, Józef Tischner. Wieści ze stuchanicy. Kraków: Znak, 2001.

Grzegorzewska, Wioletta. „Kompleks polski”. Tygodnik Powszechny 41 (2017): 60-62 . 
Hirsz, Zbigniew Jerzy. Historia polityczna Polski 1939-1993. Białystok: PPUH Book House, 1996.

Michnik, Adam, Józef Tischner, Jacek Żakowski. Między Panem a Plebanem. Kraków: Znak, 1995.

Mickiewicz, Adam. Pan Tadeusz. Paryż: A. Pinard, 1834.

Patočka, Jan. Eseje heretyckie z filozofii dziejów. Tłum. Juliusz Zychowicz. Warszawa: Fundacja Aletheia, 1998.

Postawy i wartości w okresie konfliktu społecznego, red. Stefania Dzięcielska-Machnikowska. Warszawa: KAW, 1985.

Ratzinger, Joseph. Głód Boga. Kazania z Pentling. Tłum. Paweł Kaźmierczak. Kraków: WAM, 2016.

Rousseau, Jean-Jacques. „Rozprawa o pochodzeniu i podstawach nierówności między ludźmi”. Tłum. Henryk Elzenberg. W: Jean-Jacques Rousseau, Trzy rozprawy z filozofii społecznej, 107-276. Warszawa: PWN, 1956.

Ryś, Grzegorz. Moc wiary. Kraków: WAM, 2017.

Sartre, Jean-Paul. „Wolność Kartezjańska”. Tłum. Irena Tarłowska. W: Filozofia i socjologia XX wieku, t. II, red. Bronisław Baczko, 309-330. Warszawa: Wiedza Powszechna, 1965.

Tischner, Józef. „Człowiek zniewolony i sprawa wolności”. Znak 319-320 (1981): 123-142.

Tischner, Józef. „Homo sovieticus”. Pierwodruk: Gazeta Wyborcza 10 (1991), dodatek: Gazeta Świąteczna: 5.

Tischner, Józef. Etyka solidarności. „,Homo sovieticus”. Kraków: Znak, 2005.

Tischner, Józef. Filozofia dramatu. Kraków: Znak, 1998.

Tischner, Józef. Myślenie wedlug wartości. Kraków: Znak, 1982.

Tischner, Józef. Nieszczęsny dar wolności. Kraków: Znak, 1993.

Tischner, Józef. Polski ksztalt dialogu. Paris: Editions Spotkania, 1981.

Tischner, Józef. Polski młyn. Kraków: Nasza Przeszłość, 1991.

Tischner, Józef. Świat ludzkiej nadziei. Kraków: Znak, 1975.

Tischner, Józef. Zrozumieć własna wiarę. Kraków: Znak, 2012.

Tocqueville, Alexis de. O demokracji w Ameryce. Tłum Marcin Król. Warszawa: PIW, 1976.

Torańska, Teresa. Oni. Warszawa: Aneks, 1985. 